The Digital Object Identifier - DOI: 10.37952/ROI-jbc-01/19-58-4-146

Submitted on April 10, 2019.

\title{
The identification of remains funeral food in clay molded vessels from burials by gaschromatography and mass spectrometry
}

(C) Victor M. Pojidaev, ${ }^{1+}$ Irina E. Zaytseva, ${ }^{2}$ Yana E. Sergeeva, ${ }^{1}$ and Ekaterina B. Yatsishina ${ }^{1}$

${ }^{1}$ Complex of NBICS Technologies. National Research Center "Kurchatov Institute». Akademika Kurchatova Sq., 1. Moscow, 123182. Russia. Phone: +7 (499) 196-71-00.

E-mail: pojidaev2006@yandex.ru

${ }^{2}$ Institute of Archeology RAS. Dm Ulianov St., 19. Moscow, 117036. Russia.

Phone: +7 (499) 126-47-98. E-mail: izaitseva@yandex.ru

${ }^{3}$ National Research Center "Kurchatov Institute». Akademika Kurchatova Sq., 1.

Moscow, 123182. Russia.Phone: +7 (499)196-71-00.E-mail: nrcki@nrcki.ru

\begin{abstract}
*Supervising author; ${ }^{+}$Corresponding author
Keywords: burials, ancient molded vessels, soil samples, animal fat, fatty acid compositions, gas chromatography, mass spectrometry, identification.
\end{abstract}

Abstract

The study of food products lipid residues found on external and internal surfaces of ancient clay or ceramic vessels, also their identification by chemical methods can provide valuable information about these vessels using and the food preferences of ancient people.Burial ground Shekshovo is a burial monument in Suzdal Opole, where in the course of archeological works, mound burial mounds with destroyed and undisturbed burials were detected. The samples extracts from ground filling 6 ceramic molded vessels from the burials of the XI century were investigated by gas chromatography and mass spectrometry.

The various sterols were found by chromato-mass-spectrometric study of the fat residues. The main sterols was cholesterol, with insignificant admixtures of $\beta$-sitosterol and squalene.

Monocarboxylic fatty acids (FAs) with carbon chain from 12 to 18, including lauric and myristic acids, as well as monocarboxylic acids odd-chain FAs and branch-chain FAs were detected in the studied extracts.

The presence of cholesterol, lauric and myristic, as well as the high content of palmitic and stearic acids in extracts of soil samples from vessels, indicates the presence of animal fat in the remains of burial food.

As result of comparison fatty acid profiles of soil extracts from archaeological vessels with literature data about fatty acids content of various fats, It was suggested that the remains of the burial food of three samples were contained the fat of ruminants (cattle, sheep or goats), the other three samples were contained animal fat single-chamber stomach (pigs or horses).

\section{References}

[1] R.P. Evershed, H.R. Mottram, S.N. Dudd, S. Charters, A.W. Stott, G.J. Lawrence. New criteria for the identification of animal fats preserved in archaeological pottery. Naturwissenssenchaften. 1997. Vol.84. P.402-406.

[2] M. Leclerc, K. Taché, S. Bedford, M. Spriggs, A. Lucquin, O.E. Craig. The use of Lapita pottery: Results from the first analysis of lipid residues. J. Arch. Sci.: Reports. 2018. Vol.17. P.712-722.

[3] V.M. Pojidaev, Ya.E. Sergeeva, I.S. Slushnaya, P.K. Kashkarov, E.B. Yatsishina. Application of gaschromatography to clarify the attribution of ancient clay vessel. Butlerov Communication. 2017. Vol.52. No.12. P.73-81. DOI: 10.37952/ROI-jbc-01/17-52-12-73

[4] V.M. Pojidaev, Ya.E. Sergeeva, P.K. Kashkarov, E.B. Yatsishina, E.N. Ofitserov. The investigation of organic residue from old dish surface. Butlerov Communication. 2018. Vol.56. No.11. P.47-54. DOI: 10.37952/ROI-jbc-01/18-56-11-47

[5] J. Condamin, F. Formenti, M.O. Metais, M. Mishel, P. Blond. Application of Gas-Chromatography to Tracing of Oil in Ancient Amphorae. Archaeometry. 1976. Vol.18. P.195-201.

[6] M. Patrick, A.J. Dekoning, A.B. Smith Gas-Liquid Chromatographic Analysis of Fatty-Acids in Food Residues from Ceramics Found in the Southwestern Cape, South-Africa. Archaeometry. 1985. Vol.27. P.231-236.

[7] M.E. Malainey, R. Przybylski, B.L. Sherriff. The fatty acid composition of native food plants and animals of western Canada. J. Arch. Sci. 1999. Vol.26. P.83-94.

[8] M.E. Malainey, R. Przybylski, B.L. Sherriff. The effects of thermal and oxidative degradation on the fatty acid composition of food plants and animals of western Canada: implications for the identification of archaeological vessel residues. J. Arch. Sci. 1999. Vol.26. P.95-103. 
THE IDENTIFICATION OF REMAINS FUNERAL FOOD IN CLAY MOLDED VESSELS FROM BURIALS... _ 146-155

[9] M.E. Malainey, R. Przybylski, B.L. Sherriff. Identifying the former contents of late precontact period pottery vessels from western Canada using gas chromatography. J. Arch. Sci. 1999. Vol.26. P.425-438.

[10] K.E. Peters, C.C. Walters, J.M. Moldowan. The Biomarker Guide (Vol. 1): Biomarkers and isotopes in the environment and human history. Cambridge: Cambridge University Press. 2005. 1155p.

[11] R.P. Evershed. Organic residues in archaeology: the archaeological biomarker revolution. Archaeometry. 2008. Vol.50. P.895-924.

[12] S. Hammann, L.J.E. Cramp. Towards the detection of dietary cereal processing through absorbed lipid biomarkers in archaeological pottery. J. Arch. Sci. 2018. Vol.93. P.74-81.

[13] V.M. Pojidaev, Ya.E. Sergeeva, E.Yu. Tereshenko, E.B. Yatsishina, V.A. Rastorguev. The investigation of artwork pollution by chromato-mass spectrometry. Butlerov Communication. 2018. Vol.53. No.2. P.94-99. DOI: 10.37952/ROI-jbc-01/18-53-2-94

[14] R.P. Evershed, C. Heron, L.J. Goad. Analysis of organic residues of archeological origin by hightemperature gas chromatography and chromatography-mass spectrometry. Analyst. 1990. Vol.115. P.1339-1342.

[15] R.P. Evershed, C. Heron, S. Charters, L.J. Goad. The survival of food residues: New methods of analysis, interpretation and application. Proceedings of the British Academy. 1992. Vol.77. P.187-208.

[16] M. Regert. Analytical strategies for discriminating archeological fatty substances from animal origin. Mass Spectrometry Reviews. 2011. Vol.30. P.177-220.

[17] R.P. Evershed, K.I. Arnot, J. Collister, G. Eglinton, S. Charters. Application of isotope ratio monitoring gas chromatography Mass-Spectrometry to the analysis of organic residues of archeological origin. Analyst. 1994. Vol.119. P.85-95.

[18] R.P. Evershed. Experimental approaches to the interpretation of absorbed organicresidues in archeological ceramics. World Archeology. 2008. Vol.40. P.26-47.

[19] H.R. Mottram, S.N. Dudd, G.J. Lawrence, A.W. Stott, R.P. Evershed. New chromatographic, mass spectrometric and stable isotope approaches to the classification of degraded animal fats preserved in archaeological pottery. J. Chromatogr. A. 1999. Vol.833. P.209-221.

[20] R. Rottlander. Lipid analysis in the identification of vessel contents. Organic Contents of Ancient Vessels: Material Analysis and Archaeological Investigation. Eds. Biers W., McGovern P.

Philadelphia: University of Pennsylvania. 1990. 80p.

[21] S.N. Dudd, R.P. Evershed. Unusual triterpenoid fatty acyl ester components of archaeological birch bark tars. Tetrahedron Lett. 1999. Vol.40. P.359-362.

[22] S.N. Dudd, M. Regert, R.P. Evershed. Assessing microbial lipid contributions during laboratory degradations of fats and oils and pure triacylglycerols absorbed in ceramic potsherds. Org. Geochem. 1998. Vol.29. P.1345-1354.

[23] R.P. Evershed, A.W. Stott, A. Raven, S.N. Dudd, S. Charters, A. Leyden. Formation of long-chain ketones in ancient pottery vessels by pyrolysis of acyl lipids. Tetrahedron Lett. 1995. Vol.36. P.88758878 .

[24] J. Folch, M. Lees, G. Sloane-Stanley. A simple method for the isolation and purification of total lipids from animal tissues. J. Biol. Chem. 1957. Vol.226. P.497-509.

[25] V.M. Pozhidaev Y.E. Sergeeva, A.V. Kamayev. Study of archaeological artifact by chromatographymass spectrometry. J. Anal. Chem. 2017. Vol.72. No.6. P.699-702.

[26] V.M. Pozhidaev Y.E. Sergeeva, A.V. Kamayev. Study of archaeological artifact by chromatographymass spectrometry. J. Anal. Chem. 2017. Vol.72. P.699-702.

[27] J.W. Eerkens. GC-MS analysis and fatty acids rations of archeological potsherds from the western Great Basin of North America. Archaeometry. 2005. Vol.47. P.83-102.

[28] R.P. Evershed, S.N. Dudd, M.S. Copley, R. Berstan, A.W. Stott, H.R. Mottram, S.A. Buckley, Z. Crossman. Chemistry of archaeological animal fats. Accounts of Chemical Research. 2002. Vol.35. P.660-668.

[29] S.A. Buckley, R.P. Evershed. Organic chemistry of embalming agents in Pharaonic and Greco-Roman mummies. Nature. 2001. Vol.413. P.837-841.

[30] Complex organic chemical balms of Pharaonic animal mummies. Nature. 2004. Vol.431. P.294-299.

[31] T.B. Rossell. Chemistry of Lipids, in: The Chemistry of Muscle-Based Foods. Ledward, D.A., Johnstone, D.E., Knight, M.K. (Eds.). London. Royal Society of Chemistry. 1992. 330p.

[32] R.P. Evershed, S.N. Dudd, M. J. Lockhean, S. Jim. Lipids in Archaeology, in Handbook of archaeological sciences. Brothwell, D.R., Pollard, A.M. (Eds.). John Wiley \& Son Ltd. 2001. P.331-349.

[33] S.A. Buckley, K.A. Clark, R.P. Evershed. Complex organic chemical balms of Pharaonic animal mummies. Nature. 2004. Vol.431. P.294-299. 